\title{
Froin's syndrome with tuberculosis myelitis and spinal block
}

\author{
Carlos Eduardo Mantese ${ }^{1 *} \oplus$, Ricardo Lubini ${ }^{1}$
}

\section{INTRODUCTION}

Tuberculosis is a leading cause of infectious disease death worldwide among adults. It has been considered a global public health emergency for the past 25 years ${ }^{1}$. The most severe form is meningitis, which has a high morbimortality, with roughly $50 \%$ of patients dead or disabled ${ }^{2}$. An important finding, which can be caused by tuberculosis, is cerebrospinal fluid (CSF) block, with unusual high protein content caudal to it, described as Froin's syndrome.

\section{OBJECTIVE}

The aim of this study is to describe a clinical and CSF finding in Froin's syndrome caused by tuberculosis myelitis and a review on Froin's syndrome.

\section{METHODS}

The patient data were collected through hospitalization details from September 2016 to September 2018 in an ambulatory consultation.

A short study was done as a systematic review using PubMed with the terms "Froin Syndrome" or "Froin's Syndrome" for etiological identification and CSF analysis. The inclusion criteria were provided information about Froin's syndrome, and exclusion criteria were non-English and earlier than 1950. Also, we did not include abstracts. References from the articles were checked.

\section{RESULTS}

A 64-year-old diabetic female patient presented in the emergency department with acute onset of confusion and walking difficulty. Magnetic resonance imaging (MRI) showed a diffusion-weighted hypersignal in the cerebellar vermis, with initial suspicion of stroke. As the patient developed fever, CSF was collected. It showed a lymphocytic pleocytosis. We started acyclovir, cefepime, and vancomycin and then underwent fungal and tuberculosis microbiology tests. The patient worsened her clinical status with lethargy and was admitted to intensive care, where she was placed in mechanical ventilation. The results from repeated MRI revealed hydrocephalus. However, another lumbar puncture was performed with a higher white blood cell (WBC) count, neutrophilic predominance, and an unusual high protein content (Table 1). Since these abnormal proteins increased, neuraxis MRI was performed considering a spinal block (Figure 1). It showed a T2 hypersignal in the cervical spine with CSF block, confirming Froin's syndrome. Anti-tuberculous drugs were added to the scheme with corticoid and external drainage was placed for 5 days where protein chain reaction to mycobacterium was positive. During this, a thorax tomography showed a true-in-bud pattern. All antibiotics were suspended, except for tuberculosis. The patient regained her consciousness and was found with a paraparesis. She had a slow recuperation. Corticoid was withdrawn in a long-time schedule, because she usually had worse leg strength as we lower corticoid doses. After 2 years, she was able to walk with assistance with some degree of spastic paraparesis.

\section{A SHORT SYSTEMATIC REVIEW}

There were 14 references matched the search, and their abstracts were reviewed. If there were no abstract, the entire article was reviewed. Two excluded article contained a diagnostic method and non-human cases, respectively. From the remaining 12 papers, one was excluded from the final analysis because it did not have CSF analysis ${ }^{3}$. Two papers were added by searching references section. From these 13 papers, the disease has been described in many conditions with CSF analyses (Table 2).

${ }^{1}$ Hospital Mãe de Deus, Department of Neurology - Porto Alegre (RS), Brazil.

*Corresponding author: mantese@gmail.com

Conflicts of interest: the authors declare there is no conflicts of interest. Funding: none.

Received on January 29, 2020. Accepted on March 11, 2020. 
Table 1. Cerebrospinal fluid analysis from the first lumbar puncture (day 1) and the following cerebrospinal fluid analysis.

\begin{tabular}{l|c|c|c} 
& $\begin{array}{c}\text { First } \\
\text { lumbar } \\
\text { CSF }\end{array}$ & $\begin{array}{c}\text { Second } \\
\text { lumbar } \\
\text { CSF }\end{array}$ & $\begin{array}{c}\text { Ventricular } \\
\text { external } \\
\text { drainage }\end{array}$ \\
\hline White blood cell (count/mm $\left./ \mathrm{mm}^{3}\right)$ & 178 & 840 & 20 \\
\hline Lymphocytes $(\%)$ & 75 & 30 & 65 \\
\hline Glucose $(\mathrm{mg} / \mathrm{dL})$ & 67 & 64 & 58 \\
\hline Protein $(\mathrm{mg} / \mathrm{dL})$ & 590 & 2,321 & 58 \\
\hline Opening pressure $\left(\mathrm{mmH}_{2} \mathrm{O}\right)$ & 200 & 210 & - \\
\hline
\end{tabular}

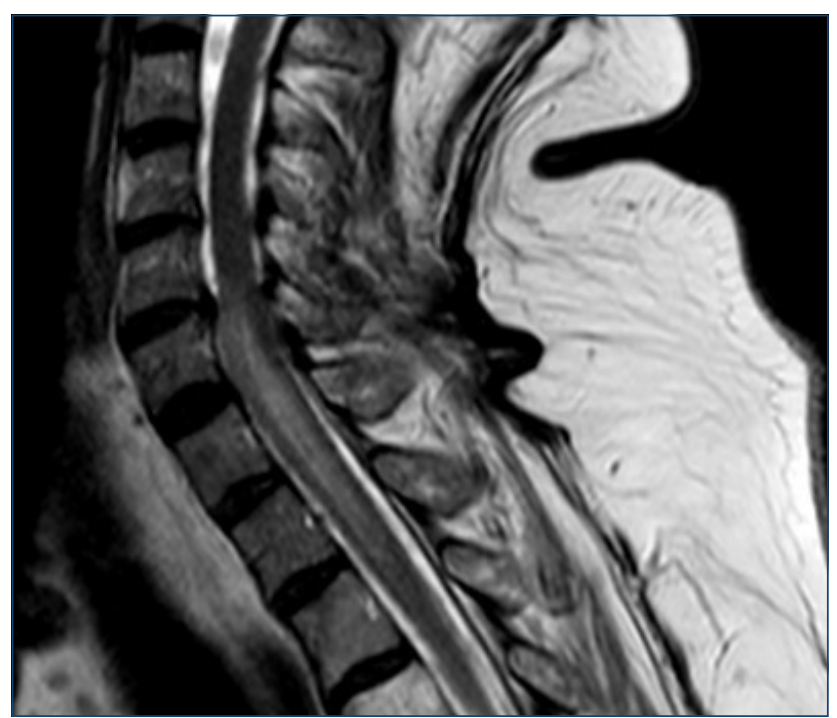

Figure 1. A T2 hypersignal in the cervical spine with cerebrospinal fluid block (Froin's syndrome).

\section{DISCUSSION}

Tuberculous meningitis is the most severe form of tuberculosis - nearly $1 \%$ of all forms of tuberculosis. Usually, it begins with nonspecific clinical manifestations, such as fatigue, fever, headache, resulting confusion and coma in few weeks ${ }^{2}$. As it progresses, it can have focal brain infarct and hydrocephalus ${ }^{17}$. In this case, the evolution was faster than expected, with acute clinical manifestations and with a rapid evolution to coma. Also, the spine can be affected by tuberculosis, the most known is Pott disease- tuberculosis spondylitis, and with spinal infarction, myelitis, and tuberculoma ${ }^{18}$. In this case, we had a spinal lesion attributed to myelitis, with CSF spinal block leading to Froin's syndrome. It showed a very high protein content caudal to the block and the relatively small increase in the external derivation CSF sample, confirming the spinal block.

Froin's syndrome was described more than 100 years ago. It is the combination of xanthochromia, elevated protein, and hypercoagulated CSF, associated with spinal block ${ }^{3}$. Initially, it was associated with neoplasm; however, it has been described as meningitis, epidural abscess, and trauma. Even only mechanical block can cause it. In our review, different mechanisms have been described. No cases were reported with tuberculosis meningitis and myelitis. Only one case was associated with tuberculosis in Pott disease context ${ }^{12}$. Three cases were associated with varicella-zoster virus encephalitis ${ }^{4,9,15}$. One of them was reported a high protein content with no block ${ }^{9}$, which is odd. The pathophysiology is thought to be due to stagnant CSF, causing passive or active diffusive processes resulting in hyperproteinosis

Table 2. Articles selected from the systematic review.

\begin{tabular}{|c|c|c|c|c|}
\hline & & Protein (mg/dL) & $\begin{array}{l}\text { White blood cell } \\
\text { count }\left(\mathrm{mm}^{3}\right)\end{array}$ & $\begin{array}{l}\text { Red blood cell } \\
\text { count }\left(\mathrm{mm}^{3}\right)\end{array}$ \\
\hline Kleinschmidt-DeMasters B.K. et al. $1998^{4}$ & $\begin{array}{l}\text { Necrotizing vasculitis by varicella- } \\
\text { zoster virus encephalomyelitis }\end{array}$ & 1,877 & 1,330 & 4,430 \\
\hline Mohee K. et al. $2012^{5}$ & CIDP and L2 disc compression & 612 & 2 & 1 \\
\hline Govindarajan R. and Khan T. $2012^{6}$ & Epidural abscess & 3,295 & Normal & 888 \\
\hline Ljevak J. et al. $2014^{7}$ & $\begin{array}{l}\text { Glioblastoma multiforme in the brain } \\
\text { and spinal cord }\end{array}$ & 1,700 & 53 & - \\
\hline Kwon S.-K. and Kim M.-W. $2014^{8}$ & Previous trauma & 3,114 & 50 & 0 \\
\hline Heckmann J.G. $2015^{9}$ & $\begin{array}{c}\text { Alzheimer plus varicella-zoster virus } \\
\text { encephalitis }\end{array}$ & 625 & 321 & - \\
\hline Dancel R. and Shaban M. $2016^{10}$ & Schwannoma & $+1,500$ & 1 & - \\
\hline Hale A.T. et al. $2018^{11}$ & Atypical teratoid/rhabdoid tumor & 1,250 & - & - \\
\hline Maharjan K. et al. $2018^{12}$ & Tuberculosis epidural abscess & $+1,500$ & - & - \\
\hline Moscote-Salazar L.R. et al. $2019^{13}$ & Epidural abscess & 1,300 & 25 & \\
\hline Sánchez Carteyron A. et al. $2019^{14}$ & $\begin{array}{c}\text { Cerebral glioblastoma multiforme with } \\
\text { canal from ventricular stagnation to } \\
\text { subarachnoid space }\end{array}$ & $+3,000$ & - & - \\
\hline Garispe A. et al. $2019^{15}$ & $\begin{array}{c}\text { Trauma and varicella-zoster virus } \\
\text { encephalitis and HIV }\end{array}$ & 1,290 & 63 & 78 \\
\hline Decramer T. et al. $2019^{16}$ & Trauma & 3,800 & - & Few \\
\hline
\end{tabular}


and hypercoagulation 5 . Moreover, one case was reported with a ventricular block ${ }^{14}$. In CSF analysis, there are wide ranges of white blood cells and red blood cells, probably related to etiology. The elevated protein level was found in all cases; as the hallmark of the syndrome, most of the cases were at extreme levels.

Our review has some limitations. We did not include papers before 1950. Also, we do not search from abstracts, which could have more descriptions, since the case reports are prevalently published as abstracts or posters.

Froin's syndrome has been described in seminal works from the beginning of the 20th century. However, nowadays, few reports are exploring the theme. We believe that it should be widespread among clinics and neurologists, because the unique aspects of the syndrome may help to diagnose and manage the diseases properly.

\section{REFERENCES}

1. Furin J, CoxH, Pai M. Tuberculosis. Lancet. 2019;393(10181):164256. https://doi.org/10.1016/S0140-6736(19)30308-3

2. Thwaites GE, van Toorn R, Schoeman J. Tuberculous meningitis: more questions, still too few answers. Lancet Neurol. 2013:12(10):9991010. https://doi.org/10.1016/S1474-4422(13)70168-6

3. Mirza S, Adams WM, Corkhill RA. Froin's syndrome revisited, 100 years on. Pseudo-Froin's syndrome on MRI. Clin Radiol. 2008;63(5):600-4. https://doi.org/10.1016/j. crad.2007.07.027

4. Kleinschmidt-DeMasters BK, Mahalingam R, Shimek C, Marcoux HL, Wellish M, Tyler KL, et al. Profound cerebrospinal fluid pleocytosis and Froin's Syndrome secondary to widespread necrotizing vasculitis in an HIV-positive patient with varicella zoster virus encephalomyelitis. J Neurol Sci. 1998;159(2):213-8. https://doi. org/10.1016/s0022-510x(98)00171-3

5. Mohee K, Sekar V, Williams S, Goulding P. An unusual cause of raised CSF protein. Pract Neurol. 2013;13(5):328-30. https:// doi.org/10.1136/practneurol-2012-000396

6. Govindarajan R, Khan T. Froin's syndrome: an uncommon mimicker of Guillain-Barre syndrome. Eur Spine J. 2012;21(8):1674-5. https://doi.org/10.1007/s00586-012-2277-0

7. Ljevak J, Poljaković Z, Adamec I, Habek M. Glioblastoma multiforme presenting as Froin's syndrome: a new face of an old foe. Acta Neurol Belg. 2014;114(4):319-20. https://doi.org/10.1007/ s13760-014-0289-8

8. Kwon S-K, Kim M-W. Pseudo-Froin's syndrome, xanthochromia with high protein level of cerebrospinal fluid. Korean J Anesthesiol. 2014;67(Suppl):S58-9. PMID: 25598909

9. Heckmann JG. Varicella zoster virus encephalitis with extreme CSF lactate and protein unmasking Alzheimer's disease. Clin

\section{CONCLUSION}

Our case had an atypical rapid evolution, but some aspects of tuberculosis meningitis had given clues to diagnosis, such as the hydrocephalus and the abnormal high CSF protein content. But the knowledge of possible Froin's syndrome improved the diagnosis work, with tuberculous myelitis-induced spinal block in a comatose patient.

\section{AUTHORS' CONTRIBUTIONS}

CEM: Conceptualization, Project administration, Supervision, Writing - original draft. CEM, RL: Data curation, Formal Analysis, Investigation, Methodology, Writing - review \& editing. All authors contributed equally to the manuscript.

Neurol Neurosurg. 2015;137:115. https://doi.org/10.1016/j. clineuro.2015.07.006

10. Dancel R, Shaban M. IMAGES IN CLINICAL MEDICINE. Froin's Syndrome. N Engl J Med. 2016;374(11):1076. https://doi. org/10.1056/NEJMicm1509557

11. Hale AT, Fricker GP, Crook TW. A case of a 4-year-old female with a primary spinal malignancy presenting with Froin's Syndrome. Pediatr Neurosurg. 2018;53(1):64-8. https://doi.org/10.1159/000481514

12. Maharjan K, Adhikari S, Basnyat B. Froin's syndrome associated with spinal tuberculosis. BMJ Case Rep. 2018;11(1):e228367. https://doi.org/10.1136/bcr-2018-228367

13. Moscote-Salazar LR, Joaquim AF, Alcala-Cerra G, Agrawal A, Calderon-Miranda WG. Froin's syndrome mimicking GuillainBarre syndrome in a patient with spinal epidural abscess. Asian J Neurosurg. 2019;14(1):338-9. https://doi.org/10.4103/ajns. AJNS_11_17

14. Sánchez Carteyron A, Saint-Lézer A, Damoo B, Ondzé B. Froin's syndrome dissemination from temporal horn entrapment after stereotactic needle biopsy. Rev Neurol (Paris). 2020;176(1-2):128-9. https://doi.org/10.1016/j.neurol.2019.01.401

15. Garispe A, Naji H, Dong F, Arabian S, Neeki M. Froin's syndrome secondary to traumatic and infectious etiology. Cureus. 2019;11(12):e6313. https://doi.org/10.7759/cureus.6313

16. Decramer T, Wouters A, Kiekens C, Theys T. Froin syndrome after spinal cord injury. World Neurosurg. 2019;127:490-1. https://doi. org/10.1016/j.wneu.2019.04.198

17. Thwaites G. Tuberculous meningitis. Medicine (Baltimore). 2017;45(11):670-3. https://doi.org/10.1016/j.mpmed.2017.08.010

18. Schaller MA, Wicke F, Foerch C, Weidauer S. Central nervous system tuberculosis: etiology, clinical manifestations and neuroradiological features. Clin Neuroradiol. 2019;29(1):3-18. https://doi.org/10.1007/s00062-018-0726-9 